\title{
Stimulation of c-myc protooncogene expression by transforming growth factor a in human ovarian cancer cells
}

\author{
Jeong-Youn Choi, ${ }^{1}$ Young-Sook Hong ${ }^{1}$ and \\ Hae-Young Park ${ }^{1,2}$ \\ 1 Department of Biochemistry, Ewha Medical Research Center, \\ College of Medicine, Ewha Womans University, Seoul 158-056, \\ Korea \\ 2 Corresponding author
}

Accepted 23 September 1997

Abbreviations: TGF $\alpha$, transforming growth factor $\alpha$; FBS, fetal bovine serum; OPT, phosphorothioate oligonucleotides

\begin{abstract}
To investigate whether transforming growth factor $\alpha$ (TGF $\alpha$ ) treatment of human ovarian cancer cells was associated with the induction of c-myc protooncogene, the expression of this gene in NIH:OVCAR-3 cells was examined. TGF $\alpha$ induced increase in c-myc mRNA level, with a peak after $1 \mathrm{~h}$ of treatment; this stimulation was dose-dependent, with an optimal concentration of $5 \mathrm{ng} / \mathrm{ml} \mathrm{TGF} \alpha$. Its primary action is probably at the transcription level since the half-life of c-myc mRNA measured in the presence of actinomycin D was not modified by TGF $\alpha$ treatment. In addition, TGF $\alpha$ stimulation of c-myc mRNA did not require protein synthesis since it was not suppressed by cycloheximide treatment. Antisense phosphorothioate oligonucleotide to c-myc specifically inhibited the TGF $\alpha$-stimulated $c-M y c$ protein expression and growth of NIH:OVCAR-3 cells. Our results indicate that induction of c-myc expression by TGF $\alpha$ plays an important role in the growth of NIH:OVCAR-3 cells.
\end{abstract}

Keywords: c-myc, ovarian cancer cells, TGF $\alpha$

\section{Introduction}

Ovarian cancer is the most fatal gynecological malignancy, and although a great deal of effort has been devoted to it, prognosis has not been significantly improved. This is due in part to the occult nature of the malignancy as well as the fact that ovarian cancer's mechanism for growth regulation is as yet well known. Recent studies demonstrate that oncogenes, growth factors and their cognate receptors are involved in the genesis and proliferation of neoplasms (Kommoss et al., 1992; Berck and MartinezMaza, 1994). The growth factors that may be involved in the pathogenesis of ovarian cancers, such as epidermal growth factor (EGF) or transforming growth factor $\alpha$ (TGF $\alpha$ ), are being studied (Zhou and Leung, 1992), and a positive correlation between the TGF $\alpha$ and c-myc expression in ovarian cancer was reported (Bauknecht et al., 1990). However, the relationship between these growth factors and cancer initiation, growth regulation of ovarian epithelial cells or growth of ovarian cancer cells remain largely unknown. TGF $\alpha$, which has high structural homology to EGF, also binds to EGF receptor and exhibits EGF-like biological activities. That it functions as an autocrine factor has been reported for a number of malignant cells in culture.

The expression of the c-myc protooncogene is closely correlated with cell proliferation and differentiation (Meichle et al., 1992). An increase in the expression of c-myc gene by TGF $\alpha$ has been observed in a variety target tissues (Cutry et al., 1989; Skouteris and McMenamin, 1992; Oliver et al., 1995). Despite investigation in a variety of normal and neoplastic cells, the fundamental aspects of the kinetics and mechanisms underlying c-myc expression modulated by TGF $\alpha$ and the significance of its induction remain undetermined. The goal of this study was to investigate the role of c-myc expression and the mechanisms of the regulation by TGF $\alpha$ in ovarian cancer cells.

\section{Materials and Methods}

\section{Cell culture}

$\mathrm{NIH}$ :OVCAR-3 cells (ATCC, Rockville, MD) were grown as monolayer culture at $37^{\circ} \mathrm{C}$ in a humidified atmosphere of $95 \%$ air and $5 \% \mathrm{CO}_{2}$ in RPMI 1640 medium supplemented with $2 \mathrm{mM}$ L-glutamine, $10 \mathrm{mM}$ HEPES, 100 units $/ \mathrm{ml}$ penicillin, $100 \mu \mathrm{g} / \mathrm{ml}$ streptomycin and $10 \%$ heatinactivated fetal bovine serum (FBS).

For the experiments, cells were incubated for various periods in fresh medium containing $1 \%$ FBS and different concentrations of TGF $\alpha$. In cycloheximide experiments, cells were treated with $10 \mu \mathrm{g} / \mathrm{ml}$ cycloheximide and TGF $\alpha$ for $50 \mathrm{~min}$. In c-myc mRNA stability analysis, cells were exposed to TGF $\alpha$ for $50 \mathrm{~min}$, actinomycin $D$ at a final concentration of $5 \mu \mathrm{g} / \mathrm{ml}$ was then added and incubated for another 0-120 min. All cells were used within 10 passages from the original stock.

\section{Cell growth rate}

For plotting cell growth curves, cells were plated in 24well tissue culture plates and incubated with $1 \%$ FBS in 
the presence or absence of $5 \mathrm{ng} / \mathrm{ml}$ TGF $\alpha$. After 2-8 days, the medium was removed, and the cells were detached with trypsin-EDTA. The viability of the cells was estimated by the trypan blue dye $(0.4 \%)$ exclusion technique, and the number of cells was counted in a hemocytometer.

\section{Extraction of RNA and Northern blot}

Total RNA was extracted by using Ultraspec II (Biotecx) and quantified by absorption at $260 \mathrm{~nm}$. For Northern blot studies, $20 \mu \mathrm{g}$ of total RNA was denatured in $50 \%$ formamide and fractionated in 1.0\% agarose/formaldehyde gel. RNA was transferred to nylon membrane (Boehringer Mannheim) by a downward alkaline transfer method (Chomczynski, 1992). Membranes were hybridized in $0.25 \mathrm{M}$ sodium phosphate buffer, $\mathrm{pH}$ 7.2, $1 \mathrm{mM}$ EDTA, $20 \%$ SDS, $0.5 \%$ blocking solution (Boehringer mannheim) and digoxigenin (DIG)-labeled human c-myc probe at $68^{\circ} \mathrm{C}$ for $18 \mathrm{~h}$. They were washed then three times in 20 $\mathrm{mM}$ sodium phosphate buffer, $\mathrm{pH} 7.2,1 \mathrm{mM}$ EDTA and $10 \%$ SDS at $65^{\circ} \mathrm{C}$. DIG-labeled hybridization signal was detected using DIG luminescent detection kit (Boehringer Mannheim) as manufacturer's protocol. Relative intensity of hybridization signals were quantified by laser densitometer (LKB). The human c-myc probe was obtained from ATCC, and a $1.4 \mathrm{~kb} \mathrm{Clal} / E c o R I$ fragment, containing third exon of the human c-myc gene, was used and labeled with DIG-11-dUTP by using random primed DNA labeling kit (Boehringer Mannheim). Cyclophilin was used as a control.

\section{Phosphorothioate oligonucleotides (OPTs)}

A 15-mer antisense OPT (5'-AACGTTGAAGGGCAT-3') complementary to the translation initiation region of c-myc mRNA was used. As a control, a sense OPT (5'-ATGCC CCTCAACGTT-3') were used in different experiments. OPTs were synthesized, purified and dried under vacuum by Bioneer, Inc., Korea. OPTs were resuspended in sterile PBS.

\section{Western blot analysis of c-Myc protein}

After a 4-day treatment with $5 \mu \mathrm{M}$ antisense c-myc or sense c-myc OPT, NIH:OVCAR-3 cells were stimulated with TGF $\alpha(5 \mathrm{ng} / \mathrm{ml})$ for an additional $2 \mathrm{~h}$, and then lysed directly in lysis buffer (50 mM Tris, $\mathrm{pH} 8.0,150 \mathrm{mM} \mathrm{NaCl}$, $1 \%$ Triton X-100, $0.2 \mathrm{mM}$ phenylmethylsulfonylfluoride and $1 \mu \mathrm{g} / \mathrm{ml}$ aprotinin). The samples were loaded onto $10 \%$ SDS-polyacrylamide gel, electrophoresed, and then transferred to a PVDF membrane (Amersham, UK). The membrane was incubated with anti-human c-Myc monoclonal anti-body (Oncoscience, Cambridge, MA) and then with horseradish peroxidase-conjugated goat antimouse antibody (Transduction Lab., Lexington, KY). Peroxidase activity was then detected following incubation with 4-chloro-1-naphtol, diaminobenzidine and hydrogen peroxide.

\section{Effect of antisense c-myc DNA on cell growth}

For the analysis of the effect on cell growth of antisensemyc OPT, cells were plated in 96-well plates. After pretreated with serum-free medium for $48 \mathrm{~h}$, cells were incubated in the fresh medium containing $1 \%$ FBS, 5 $\mathrm{ng} / \mathrm{ml} \mathrm{TGF} \alpha$, and $5 \mu \mathrm{M}$ of antisense-myc or sense- $m y c$ OPT for 4 days. Cell growth was assessed by XTT assay. At the end of incubation, cells were incubated with the XTT labeling mixture (Boehringer Mannheim) for $4 \mathrm{~h}$ and then the formazan dye formed is quantitated using an ELISA reader (Molecular Devices). Preliminary experiments were performed to establish that the absorption characteristics for NIH:OVCAR-3 cells would allow reproducible quantification of viable cell numbers within the range of cell density used in the proliferation experiments and that TGF $\alpha$ stimulation has no primary effect on the tetrazolium-reducing activity of NIH:OVCAR-3 cells.

\section{Results}

\section{Effect of TGF $\alpha$ on cell growth}

Cell growth was assessed by cell counting. As shown in Figure 1, the addition of $5 \mathrm{ng} / \mathrm{ml} \mathrm{TGF} \alpha$ caused a 1.8fold increase in the growth of cells, compared to control cells.

\section{c-myc mRNA induction by TGF $\alpha$}

Cells were treated with $5 \mathrm{ng} / \mathrm{ml}$ TGF $\alpha$. c-myc mRNA levels were measured by Northern blotting at various times for up to $24 \mathrm{~h}$. TGF $\alpha$ stimulated c- myc mRNA level with a peak $(4.0 \pm 0.5$ fold $)$ at $1 \mathrm{~h}$ after treatment (Figure 2$)$. Cells were also treated for $1 \mathrm{~h}$ with various concentrations of TGF $\alpha$ and c-myc mRNA analyzed by Northern blot. The

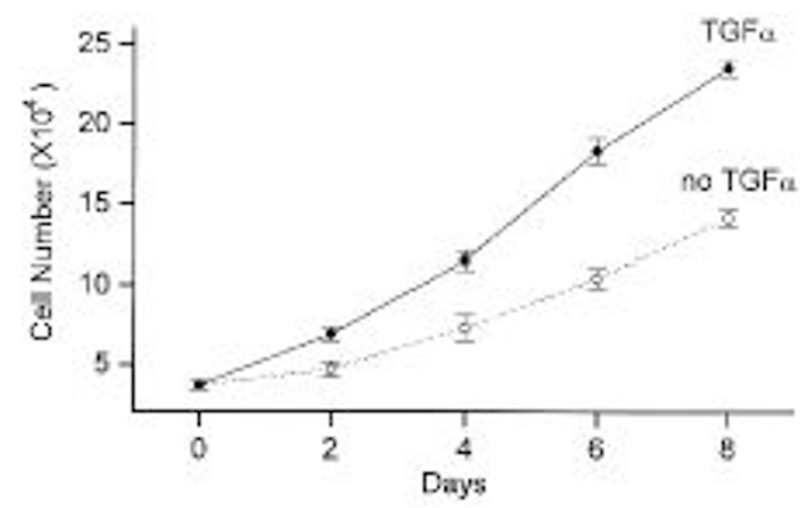

Figure 1. Effect of TGF $\alpha$ on the growth of ovarian cancer NIH:OVCAR-3 cells. Cells were incubated in fresh $1 \%$ FBS media in the presence or absence of $5 \mathrm{ng} / \mathrm{ml} \mathrm{TGF} \alpha$. The cells were harvested and cell number counted on the days indicated. Results are expressed as the mean values \pm SD of three different experiments. 


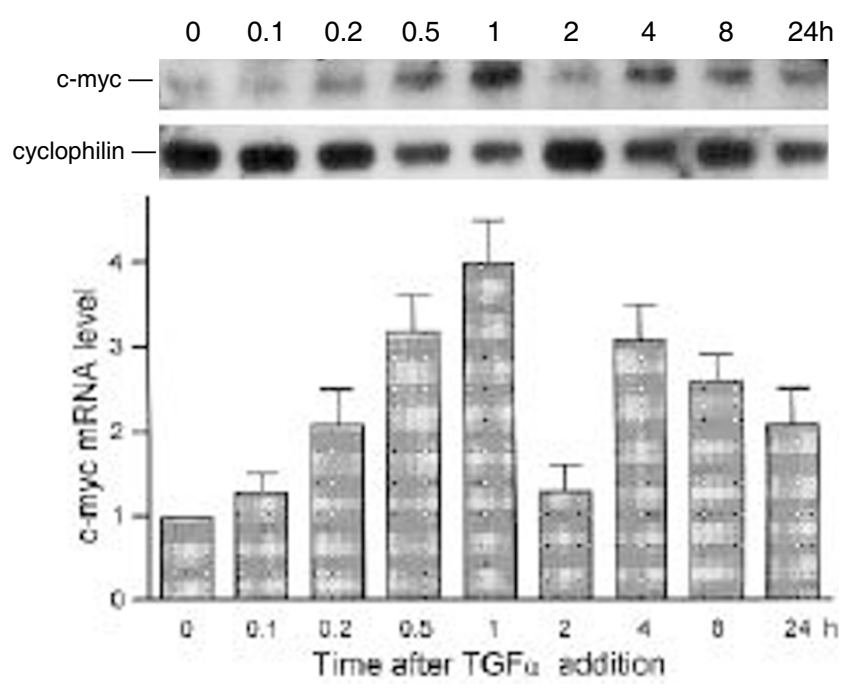

Figure 2. Time course of TGF $\alpha$-stimulated c-myc mRNA expression. Cells were treated with $1 \%$ FBS media containing $5 \mathrm{ng} / \mathrm{ml}$ TGF $\alpha$ for the time designated. At the end of treatment, RNA were extracted and subjected to Northern blot analysis. Upper panel, Chemiluminescent hybridization signals of Northen blot. Cyclophilin mRNA in the samples was measured as a control. Lower panel, Quantification of the c-myc mRNA levels are normalized on the basis of the level observed before adding TGF $\alpha$, considered as 1 . Results are expressed as the mean values \pm SD of four different experiments.

stimulation of c-myc was TGF $\alpha$ dose-dependent and the highest level being reached with the dose of $5 \mathrm{ng} / \mathrm{ml}$ TGF $\alpha$ (Figure 3).

\section{Effect of cycloheximide on induction of c-myc mRNA by TGF $\alpha$}

Modulation of the levels of mRNA species by a particular agent can occur in the absence of protein synthesis if this is a primary response to the agent. Therefore, the effect of the protein synthesis inhibitor, cycloheximide, on the stimulation of c-myc by TGF $\alpha$ was tested to determine whether new protein synthesis is required. Cells were treated with vehicle control, $5 \mathrm{ng} / \mathrm{ml} \mathrm{TGF} \alpha$, or $10 \mu \mathrm{g} / \mathrm{ml}$ cycloheximide alone or with $5 \mathrm{ng} / \mathrm{ml}$ TGF $\alpha$ plus $10 \mu \mathrm{g} / \mathrm{ml}$ cycloheximide. Total cellular RNA was isolated after 50 min of treatment and subjected to Northern blot. When cycloheximide was added together with TGF $\alpha$, the transcript level increased $490 \pm 24 \%$ of control (Figure 4 ). This increase was higher than that observed with TGF $\alpha$ alone. Therefore, cycloheximide does not prevent TGF $\alpha$ from stimulating c-myc expression. These results suggest additive effects since cycloheximide alone induced a $90 \%$ increase in the c-myc mRNA level. This cycloheximide action has been observed in other model systems and is primarily due to prolongation of mRNA half-life resulting from the inactivation of a labile regulatory protein, known to destabilize c-myc mRNA (Kelly et al., 1983; Miano et

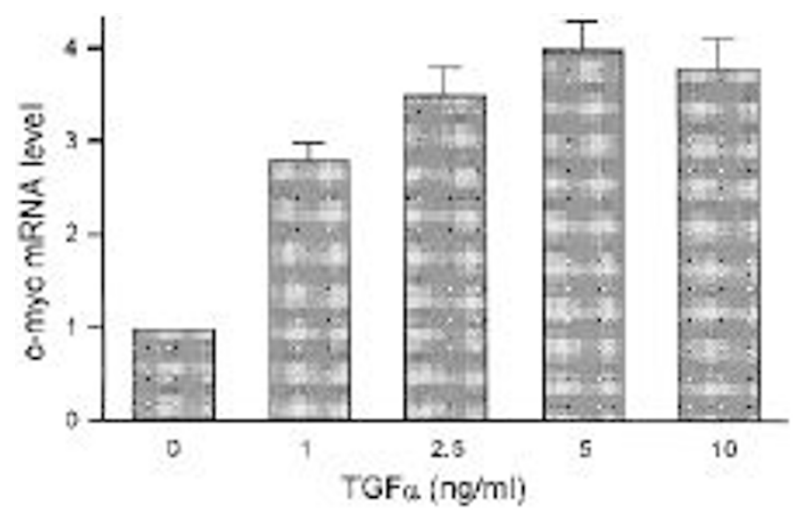

Figure 3. Dose response of TGF $\alpha$-stimulated c-myc mRNA expression. Cells were treated with $1 \%$ FBS and various concentrations of TGF $\alpha$ and RNA was extracted $1 \mathrm{~h}$ later for Northern blot analysis. Quantification of the c-myc mRNA levels are normalized on the basis of the level observed before adding TGF $\alpha$, considered as 1. Results are expressed as the mean values $\pm S D$ of three different experiments.

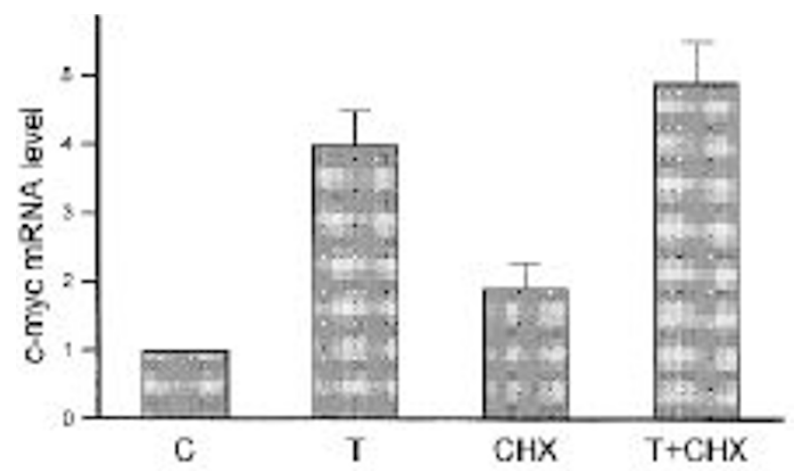

Figure 4. Effect of cycloheximide on c-myc mRNA expression. Cells were treated with control vehicle, TGF $\alpha(5 \mathrm{ng} / \mathrm{ml})$, cycloheximide $(10 \mu \mathrm{g} / \mathrm{ml})$, or combination of TGF $\alpha$ and cycloheximide for $50 \mathrm{~min}$. RNA was extracted and subjected to Northen blot analysis. Quantification of the c-myc mRNA levels are normalized on the basis of the level observed in control vehicle only, considered as 1 . Results are expressed as the mean values $\pm \mathrm{SD}$ of three different experiments. $\mathrm{C}$, control vehicle (1\% FBS only); $\mathrm{T}$, TGF $\alpha$; CHX, cycloheximide.

al., 1993; Yokota et al., 1995). These results show TGF $\alpha$ increased c-myc mRNA level in NIH:OVCAR-3 cells to the same extent with or without cycloheximide, suggesting that new protein synthesis was not required for this stimulation.

\section{c-myc mRNA stability analysis}

In order to verify TGF $\alpha$ has a stabilizing action on c-myc mRNA, the half-life of this transcript was studied in the presence or absence of TGF $\alpha$. Cells were exposed to 5 $\mathrm{ng} / \mathrm{ml} \mathrm{TGF} \alpha$ for $50 \mathrm{~min}$ and then actinomycin $\mathrm{D}$ at a concentration of $5 \mu \mathrm{g} / \mathrm{ml}$ was added. The degradation of existing c-myc mRNA was monitored at various time 


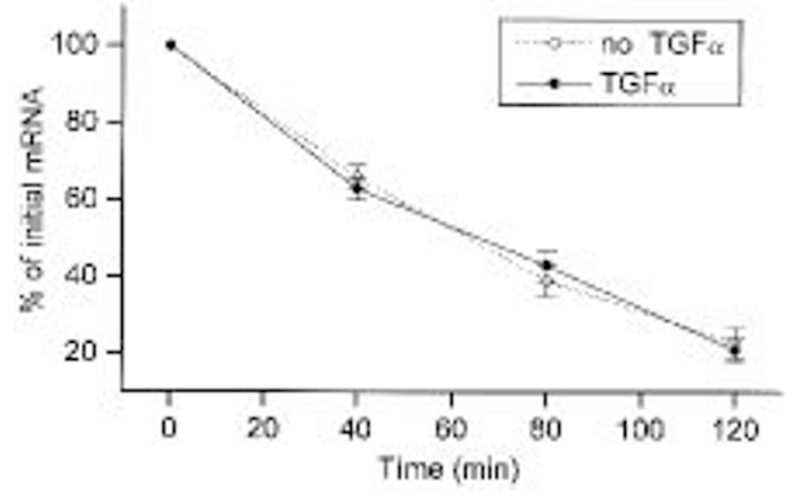

Figure 5. Stability of c-myc mRNA. Cells were cultured in the presence or absence of 5 $\mathrm{ng} / \mathrm{ml}$ TGF $\alpha$ for $50 \mathrm{~min}$. Cells were then treated with $5 \mu \mathrm{g} / \mathrm{ml}$ of actinomycin $D$ for the time indicated. RNA was extracted and subjected to Northern blot analysis. Results are expressed as the mean values $\pm S D$ of three different experiments.

intervals for a period of $120 \mathrm{~min}$. The half-life of $c-m y c$ mRNA of NIH:OVCAR-3 cells was estimated to be $64 \pm$ $5 \mathrm{~min}$ in the presence or absence of TGF $\alpha$ (Figure 5). The results suggest that TGF $\alpha$ has no effect on the cmyc mRNA stability in NIH:OVCAR-3 cells.

\section{Effect of antisense c-myc oligonucleotide on cell growth}

In order to study the effect of antisense inhibition of c-myc, c-Myc pretein expression and cell growth of NIH:OVCAR3 cells were assessed by Western blot and XTT assay, respectively. When cells were incubated in medium containing $1 \% \mathrm{FBS}, 5 \mathrm{ng} / \mathrm{ml} \mathrm{TGF} \alpha$, and $5 \mu \mathrm{M}$ antisensemyc or sense-myc OPT for 4 days, antisense-myc OPT inhibited TGF $\alpha$-stimulated c-Myc protein expression and cell growth. The sense-myc OPT had a negligible effect on c-Myc protein expression and cell growth at the same concentration. These findings suggest that C-Myc protein plays important roles in the mechanism of TGF $\alpha$-induced cell growth (Figure 6 and 7).

\section{Discussion}

In the present investigation, treatment of $\mathrm{NIH}$ :OVCAR-3 cells with $5 \mathrm{ng} / \mathrm{ml}$ TGF $\alpha$ resulted in a 1.8-fold increase in cell growth, suggesting a fully functional EGF receptor system. c-myc protooncogene is involved in regulating cell proliferation (Kelly et al., 1983; Kaczmarek et al., 1985; Studzinski et al., 1986), and seems to be one of the key genes required for a cell to progress through the cell cycle (Shichiri et al., 1993). Its expression is activated by several mitogenic factors including TGF $\alpha$. In this study, we have studied the mRNA expression of $c-m y c$ in human ovarian cancer cells as an indicator of possible protooncogene mediation of the signals transmitted by

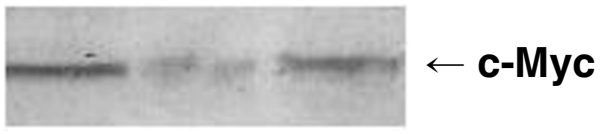

Figure 6. Effect of antisense c-myc OPT on c-Myc protein expression. Cells were incubated in fresh medium containing $1 \%$ FBS and $5 \mathrm{ng} / \mathrm{ml} \mathrm{TGF} \alpha$ in the presence or absence of $5 \mu \mathrm{M}$ OPTs. c-Myc protein expression was assessed by Western blot analysis. C, 1\% FBS + TGF $\alpha$, no OPT; AS, antisense c-myc OPT-treated; S, sense cmyc OPT-treated.

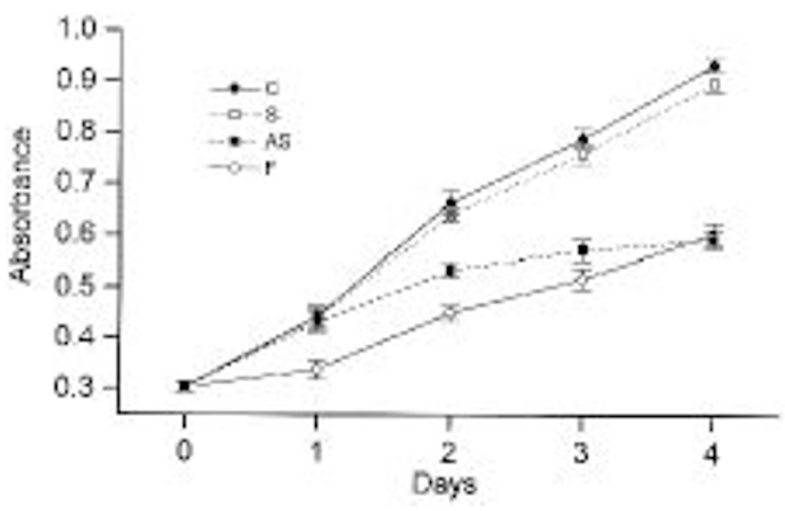

Figure 7. Effect of antisense-myc OPT on cell growth. Cells were incubated in fresh medium containing $1 \% \mathrm{FBS}$ and $5 \mathrm{ng} / \mathrm{ml}$ TGF $\alpha$ in the presence or absence of $5 \mu \mathrm{M}$ OPTs. Cell growth was assessed by XTT assay. Results are expressed as the mean values \pm SD of four wells of three independent experiments. $F, 1 \% \mathrm{FBS}$, unstimulated; C, $1 \%$ FBS + TGF $\alpha$, no OPT; AS, antisense c-myc OPT-treated; S, sense c-myc OPTtreated.

TGF $\alpha$.

We have found that TGF $\alpha$ increased the c-myc mRNA expression and the proliferation of human ovarian cancer $\mathrm{NIH}$ :OVCAR-3 cells. Moreover, antisense c-myc oligonucleotide treatment resulted in the inhibition of TGF $\alpha$ stimulated c-Myc protein expression and cell proliferation. These findings suggest that $\mathrm{C}-\mathrm{Myc}$ protein plays important roles in the mechanism of TGF $\alpha$-induced cell growth. As a cell cycle regulator (Studzinski et al., 1986), the c-Myc protein has been shown to be a target of growth factor (Luscher et al., 1989); it can also act as a transcription factor (Schweinfest et al., 1988; Penn et al., 1990). In this sense, the c-Myc protein may play a role in regulating the expression of certain growth-related genes in TGF $\alpha$ stimulated cells.

Detailed time-course studies showed that TGF $\alpha$ treatment was apparently associated with biphasic induction of c-myc mRNA. The biphasic pattern of c-myc mRNA stimulation by TGF $\alpha$ can be due to a combination of several regulatory mechanisms that are known to modul- 
ate the expression of this protooncogene, both at the transcriptional and post-transcriptional levels (Spencer and Groudine, 1991; Marcu et al., 1992). A negative autoregulatory loop may contribute such a combination (Grignani et al., 1990).

This stimulation of c-myc mRNA expression by TGF $\alpha$ does not require protein synthesis, since it is not inhibited by cycloheximide. The half-life of c-myc mRNA was not modified by TGF $\alpha$. It therefore seems that the TGF $\alpha$ action is not due to a stabilization of c-myc mRNA. The stability of RNA was known to be regulated by polyadenylated RNA species (Swartwout and Kinniburgh, 1989), or by $\mathrm{A}+\mathrm{U}$ rich element RNA binding factor (Brewer, 1991); apparently it is not altered by TGF $\alpha$ as demonstrated in this study.

The signal transduction pathway of TGF $\alpha$ in stimulation of c-myc expression have been examined in other tissues. In rat hepatocyte cultures, TGF $\alpha$ increased cmyc expression and this effect was overcome by the presence of an antibody against TGF $\alpha$ in the hepatocyte culture medium (Skouteris and McMenamin, 1992). A clear link emerged between c-myc activation and coupling of TGF $\alpha$ with its receptor. Furthermore, indomethacin inhibited the TGF $\alpha$-induced hepatocyte DNA syhnthesis, prostaglandin production and at the same time TGF $\alpha$ induced c-myc expression. Prostaglandins added to hepatocyte cultures supplemented with indomethacin and TGF $\alpha$ restored the ability of TGF $\alpha$ to stimulate DNA synthesis and to increase c-myc expression. Thus prostaglandins mediate the transduction of TGF $\alpha$-generated signals. These data suggest that TGF $\alpha$ induces hepatocyte proliferation and c-myc expression either through coupling with its receptor or through activation of arachidonic acid metabolism (Skouteris and McMenamin, 1992). On the other hand, in rat small intestinal epithelial cells (IEC-6 cells) TGF $\alpha$ stimulation of IEC- 6 cells increases the activities of 42- and 44-kDa isoforms of mitogen-activated protein kinase (MAPK). And the increase in activities of these enzymes leads to an increase in the synthesis of c-Fos and c-Myc protein levels as well as mRNA levels, suggesting a link to nuclear events (Oliver et al., 1995).

In conclusion, c-myc protooncogene is expressed and stimulated by TGF $\alpha$ in $\mathrm{NIH}$ :OVCAR-3 ovarian cancer cells. In these cells, therefore, the growth-promoting effect of TGF $\alpha$ may, at least partly, be mediated through c-myc stimulation. As a consequence, any abnormality in this process could result in cell growth disregulation. Further studies are underway to understand the exact mechanisms of TGF $\alpha$ action, at the transcriptional and/ or posttranscriptional levels.

\section{Acknowledgement}

This study was supported by a grant from Molecular Biology Research Fund, the Ministry of Education, Korea.

\section{References}

Armelin, H. A., Armelin, M. C. S., Kelly, K., Stewart, T., Leder, P., Lochran, B. H. and Stiles, C. D. (1984) Functional role for c-myc in mitogenic response to platelet-derived growth factor. Nature 310: 655-660

Bauknecht, T., Birmelin, G. and Kommoss, F. (1990) Clinical significace of oncogenes and growth factors in ovarian carcinomas. J. Steroid Biochem. Mol. Biol.37: 855-862

Berek, J. S. and Martinez-Meza O. (1994) Molecular and biologic factors in the pathogenesis of ovarian cancer. J. Reprod. Med. 39: 241-248

Brewer, G. (1991) An A + U-rich element RNA-binding factor regulates c-myc mRNA stability in vitro. Mol. Cell. Biol. 11: 2460-2466

Chomczynski, P. (1992) One-hour downward alkaline capillary transfer for blotting of DNA and RNA. Anal. Biochem. 201: 134-139

Grignani, F., Lombardi, L., Inghirami G., Sternas, L., Cechova, L. and Dalla-Favera, R. (1990) Negative autoregulation of c-myc gene expression is inactivated in transformed cells. EMBOJ. 9: 3913-3922

Kaczmarek, L., Hyland J. K., Watt R., Rosengerg M. and Beserga R. (1985) Microinjected c-myc as a competence factor. Science 228: 1313-1315

Kelly, K., Cochran, B. H., Stiles, C. D. and Leder, P. (1983) Cell-specific regulation of the $\mathrm{C}-\mathrm{myc}$ gene by lymphocyte mitogenes and platelet-derived growth factor. Cell 35 : $603-610$

Kommoss, F., Bauknecht, T., Bermelin, G., Kohler, M., Tesch H. and Pfleiderer, A. (1992) Oncogene and growth factor expression in ovarian cancer. Acta. Obstet. Gynerol. Scand. 71 suppl. 155: 19-24

Luscher, B., Kuenzel, E. A., Krebs, E. G. and Eisenman, R. N. (1989) Myc oncoproteins are phosphorylated by casein kinaqse II. EMBO J. 8: 1111-1119

Marcu, K. B., Bossone, S. A. and Patel, A. J. (1992) Myc function and regulation. Annu. Rev. Biochem. 61: 809-860

Meichle, A., Kinniburgh, A. J., Krabak, M. J., Hui, S. W. and Wenner, C. E. (1989) Induction of c-fos and c-myc proto-oncogene expression by epidermal growth factor and transforming growth factor- $\alpha$ is calcium-independent. J. Biol. Chem. 264: 19700-19705

Miano, J. M., Vlasic, N., Tota, R. R. and Stemerman, M. B. (1993) Smooth muscle cell immediate-early gene and growth factor activation follows vascular injury. A putative in vivo mechanism for autocrime growth. Artherioscl. Thromb. 13: 211-219

Oliver, B. L., Shaafi, R. I. and Hajjar, J. J. (1995) Transforming growth factor- $\alpha$ and epidermal growth factor activate mitogen-activated protein kinase and its substrates in intestinal epithelial cells. Proc. Soc. Exp. Biol. Med. 210: 162-170

Penn, L. J. Z., Brooks, M. W., Laufer, E. M. and Land, H. (1990) Negative autoregulation of c-myc transcription. EMBO J. 9: 1113-1121

Schweinfest, C. W., Fujiwara, S., Lau, L. F. and Papas, T. S. (1988) c-myc can induce expression of $G_{0} / G_{1}$ transition genes. Mol. Cell. Biol. 8: 3080-3087

Shichiri, M., Hanson, K. D. and Sedivy, J. M. (1993) Effects of c-myc expression on proliferation, quiescence, and the $G_{0}$ to $G_{1}$ transition in non-transformed cells. Cell Growth Diff. 4: 93-104

Skouteris, G. G. and McMenamin, M. (1992) Transforming growth factor- $\alpha$ induced DNA synthesis and c-myc expression in primary rat hepatocyte cultures is modulated by indomethacin. Biochem. J. 281: 729-733

Spencer, C. A. and Groudine, M. (1991). Control of c-myc regulation in normal and neoplastic cells. Adv. Cancer Res. 56: 1-48

Studzinski, G. P., Brelvi, Z. S., Feldman, S. C. and Watt, R. A. (1986) Participation of CMyc protein in DNA synthesis of human cells. Science 234: 467-470

Swartwout, S. G. and Kinniburgh, A. (1989) c-myc RNA degradation in growing and differentiating cells: possible alternate pathways. Mol. Cell. Biol. 9: 288-295

Yokota, T., Kanamoto, R. and Hayashi, S. (1995) c-myc mRNA is stabil-ized by 
deprivation of amino acids in primary cultured rat hepatocytes. J. Nutrit. Sci. Vitamirol. 41: $455-463$

Zhou, L. and Leung B.S. (1992) Growth regulation of ovarian cancer cells by epidermal growth factor and transforming growth factors $\alpha$ and $\beta 1$. Biochim. Biophys. Acta 1180: $130-136$ 